\title{
Beyond Supporting Access to Land in Socio-Technical Transitions. How Polish Grassroots Initiatives Help Farmers and New Entrants in Transitioning to Sustainable Models of Agriculture
}

\author{
Robert Skrzypczyński *(D), Sylwia Dołzbłasz (D), Krzysztof Janc (D) and Andrzej Raczyk (D) \\ Institute of Geography and Regional Development, Faculty of Earth Sciences and Environmental Management, \\ University of Wroclaw, Kuznicza 49-55 Street, 50-138 Wroclaw, Poland; sylwia.dolzblasz@uwr.edu.pl (S.D.); \\ krzysztof.janc@uwr.edu.pl (K.J.); andrzej.raczyk@uwr.edu.pl (A.R.) \\ * Correspondence: robert.skrzypczynski@uwr.edu.pl
}

Citation: Skrzypczyński, R.; Dołzbłasz, S.; Janc, K.; Raczyk, A. Beyond Supporting Access to Land in Socio-Technical Transitions. How Polish Grassroots Initiatives Help Farmers and New Entrants in Transitioning to Sustainable Models of Agriculture. Land 2021, 10, 214 https://doi.org/10.3390/land10020214

\section{Academic Editors:}

Carlos Parra-López and Purushothaman Abhilash

Received: 31 December 2020

Accepted: 17 February 2021

Published: 21 February 2021

Publisher's Note: MDPI stays neutral with regard to jurisdictional claims in published maps and institutional affiliations.

Copyright: (c) 2021 by the authors. Licensee MDPI, Basel, Switzerland. This article is an open access article distributed under the terms and conditions of the Creative Commons Attribution (CC BY) license (https:/ / creativecommons.org/licenses/by/ $4.0 /)$.
Abstract: The importance of agri-food systems for global sustainability calls for researching and advancing socio-technical transitions towards environmentally friendly models of farming. These transitions hinge on many prerequisites, one of which is providing access to land for farmers and new entrants who experiment with sustainable farming models. However, for socio-technical transitions in farming to be viable, access to land should be complemented with securing access to "intangible" resources such as skills, knowledge or networks. It seems that increasingly often these resources are being provided by various grassroots initiatives. The goal of this paper is to identify how the strategies employed by grassroots initiatives support farmers and new entrants in transitioning to sustainable farming models. In order to answer that question, we perform case studies of three Polish initiatives-Agro-Perma-Lab, PermaKultura.Edu.PL and the Ecological Folk High School in Grzybów-active in promoting agroecology, permaculture and organic farming. The results show a diversity of strategies employed by these initiatives that reflect the frameworks in which they operate. Considering these strategies from the perspective of transition studies suggests that they can be replicated in other contexts and potentially contribute to advancing socio-technical transitions of agri-food systems.

Keywords: socio-technical transitions; grassroots initiatives; agri-food systems; access to land; intangible resources; agroecology; permaculture; organic farming; new entrants into farming

\section{Introduction}

Agriculture today plays a significant role in reaching or transgressing several planetary boundaries that define a safe operating space of humans on Earth [1]. High resource intensity of contemporary agri-food systems contributes to climate change, global biodiversity loss, water scarcity events as well as imbalances in biogeochemical flows and land-use change patterns [2]. Along with the growing global population, expansion of Global North consumption patterns into other parts of the world, possible land competition between food and energy production, as well as food waste along supply chains, these impacts are projected to become even more exacerbated in the future, and technological advancements are not expected to offset them to the necessary extent [3]. In other words, business-as-usual in global agri-food systems are no longer plausible if we are to achieve Sustainable Development Goals or the objectives of the Paris Agreement [4]. There is, therefore, an urgent need for such a reinvention of agriculture that would transform it into a system able to feed the world population adequately without having to compromise for its sustainability $[5,6]$.

In recent decades, a number of approaches to farming have been proposed as alternatives to the highly mechanized and fossil-fuel dependent 'conventional' model of 
agriculture. Increasingly often, these alternatives are developed by grassroots initiatives [7] As they propose a range of possible avenues for the sustainability transition of agri-food systems, some of these initiatives are limited to selected aspects of agriculture and some aim at its radical and broad transformation, often redefining basic assumptions of how humans should use land for agricultural purposes. They cover a variety of actions, but whenever such initiatives focus on the production side of agri-food systems, they usually have one common feature: to put it simply, they require access to land on which novel approaches to farming can be verified in practice.

Access to land is not, however, a sufficient condition for the success of an initiative that intends to develop a more sustainable model of farming. It also requires access to knowledge, skills, peer networks and personal competences, i.e., resources that are less 'tangible' than land, machinery, capital or labor needed for a farm to operate [8]. This is particularly relevant for new entrants into farming, who in fact face a double obstacle: not only do they need to successfully establish their farm but also to make it work along the lines of the alternative model of farming they follow. At the same time, new entrants are recognized as agents who contribute to generational renewal and bring innovation into rural areas with all the associated benefits for local development [9]. There is, therefore, a need to recognize how farmers-and particularly new entrants-can be supported in setting up and running innovative farms that could contribute to local rural development and demonstrate whether more sustainable ways of food production are possible. In particular, it is important to recognize how factors related to knowledge, skills and other features embodied in people and their relations (e.g., human and social capital) are relevant in the context of supporting these initiatives. The higher the knowledge base of new entrants into farming, the higher the business opportunities and better possibilities of opportunity identification [10]. Thus, knowledge transfer and utilization of new knowledge are crucial in the process of establishing a successful farm and daily farmer routine [11].

The goal of this article is, therefore, to identify in what ways new entrants into farming and established farmers in Poland are supported by grassroots organizations in terms of the aforementioned, "intangible" aspects of access to land-i.e., knowledge, skills, access to networks and critical consciousness-required for setting up and testing alternative farming models. In order to answer that question, we perform case studies of three grassroots initiatives active in Poland-Agro-Perma-Lab, PermaKultura.Edu.PL and Ecological Folk High School in Grzybów-focusing on how their activities address the problems faced by new entrants or farmers employing frameworks of agroecology, permaculture and organic (ecological) farming. We have selected these three types of alternative farming model on the one hand due to the recognition of their transformative potential by other authors [12-14], and on the other due to a noticeable activity of Polish grassroots initiatives in these fields. It is important to note that these case studies do not provide an overview of all alternative farming models; they have not been selected in order to conduct a comprehensive comparison between them, but rather to show how grassroots initiatives can contribute to developing such approaches in general. Therefore, although the studied initiatives refer to agroecology, permaculture and organic farming, the results of our research can to some extent explain similar phenomena associated with the development of, e.g., regenerative or biodynamic agriculture. Moreover, it has to be noted that we do not assess the exact outcomes of the activities of these organizations, but focus on a qualitative analysis of the strategies used by them to support farmers in transition to alternative farming approaches. Our analysis sheds light on how skills, knowledge, networking and consciousness building complement supporting access to farmland itself, but also points to the role of these aspects in agri-food sustainability transitions in general. Therefore, this paper focuses on selected aspects of socio-technical transitions only; nevertheless, we believe that it can enrich the transdisciplinary perspective on rural regenerationand access to farmland in particular-and at the same time help various stakeholders (especially grassroots initiatives themselves) in successfully developing innovations in agri-food systems. 
The remainder of this article is organized as follows: the following section (Section 2) presents the theoretical background of the study using the framework of socio-technical transitions. Section 3 describes the methodology employed in the study. Section 4 ('Results') presents the results of the case studies, and Section 5 ('Discussion') discusses them in the context of socio-technical transitions while suggesting possible relevance for rural development. The sixth, final section ('Conclusions') presents the conclusions of the study.

\section{Socio-Technical Transitions in Agri-Food Systems}

Reconfiguration of agri-food systems in a way that ensures their sustainability can be considered as an example of a socio-technical transition, i.e., a broad, structural transformation of a particular system that is a result of intertwined changes in both social and technical aspects of its functioning - that are also unavoidably embedded in wider environmental, cultural and political contexts [15]. Socio-technical transitions are complex, multi-dimensional transformations that build upon a variety of activities undertook by multiple stakeholders over long periods of time and in conditions of uncertainty and conflicting values [6]. In the case of agri-food systems, the notion of socio-technical transition implies fundamental changes along the entire food supply chain-i.e., in food production, processing, distribution, consumption or disposal patterns-as well as in business models and food-related public policies [5]. Although the process itself might certainly seem blurry, it has a clear objective, i.e., to make global agriculture sustainable. Hence the term 'sustainability transition' is also used in this context, albeit in a somewhat broader meaning that encompasses various sub-types of societal transition [16].

There are a number of possible pathways that a socio-technical transition can take, as it is made up of various initiatives undertaken by multiple actors pursuing distinct agendas in changing environments. An important role in this process is often attributed to grassroots initiatives that experiment with alternative socio-technical arrangements [17]. Rather than trying to introduce incremental modifications into the existing socio-technical regimes, these experimental initiatives aim at building coherent, alternative models that are often based on a different logic than the regime altogether $[7,18]$. This is enabled because grassroots initiatives adopt a comprehensive approach that tests how user practices, technologies and regulatory practices are working in combination, which requires a protective space, a niche, where the rules of the dominant system can be put on hold in order to nurture alternative solutions [17]. Such socio-technical experimentation conducted at the grassroots level is thus seen as a way to test and demonstrate the effects of a particular set of arrangements that, if promising, could be then replicated, up-scaled or translated into the rules of the dominant socio-technical regime.

Before a successful demonstration effect can be achieved, however, any grassroots initiative needs to secure access to resources that enable setting up the experiment in the first place. This might be particularly difficult for initiatives that aim at challenging the dominant agri-food systems, which by definition is where most resources are allocated to. In some contexts, this might spark outright, and most probably unequal competition for scarce resources between actors from niches and dominant regimes. Moreover, given that regime actors tend to have vested interests in continuing the business-as-usual scenario, such competition might be exacerbated by the danger of active suppression of grassroots initiatives [19].

In this context, access to resources-particularly those that are limited-is becoming a challenge for enacting socio-technical transitions in agri-food systems. In the Global North countries, access to appropriate land has been increasingly difficult because of factors such as loss of cultivable land due to its degradation, transformation of farmland into other land-uses, rising land prices or concentration of farmland in the hands of large corporate owners $[8,20]$. In consequence, grassroots initiatives such as e.g., community-supported agriculture (CSA) find it even harder to compete with profit-oriented actors for limited resources such as land [21]. This problem applies both to established farmers and new entrants into farming, although the latter seem to be particularly afflicted: for instance, 
in the European Union (EU) lack of access to land has been identified as the main barrier in establishing a farm by new entrants [22]. Therefore, securing access to land for new entrants into (alternative modes) of farming is particularly difficult.

Providing land for new entrants into farming is essential not only because of its role in enabling sustainability transitions of agri-food systems; it is also a key element in tackling rural decline. Rural regeneration hinges in a large part on the generational renewal of rural populations and given that in many areas the continuity of farm succession is at risk, supporting new entrants into farming is seen as a necessary strategy to secure future prosperity of rural areas in their manifold functions [8]. At the same time, new entrants often follow innovative approaches to farming [9]. Therefore, the notion of reinventing agriculture is linked to the need for regenerating rural areas, since alternative, sustainable farming models tend to, somewhat by definition, put emphasis on reducing adverse environmental or social effects of conventional agriculture that negatively affect rural areas. In other words, providing access to land for new entrants might help both in advancing sustainability transitions and in ensuring better prospects for rural regeneration processes, but these two outcomes are also internally related.

However, physical access to land is not a guarantee of the success of a particular initiative experimenting with sustainable farming models. A transition to sustainable farming requires land (as well as capital, labor and equipment) just as much as it needs relevant skills and knowledge possessed by the farmers cultivating it [8]. Gaining such competences takes place in a variety of ways, but many authors agree that access to networks that enable knowledge exchange is a key aspect of this process [18,23]. Apart from aiding professional education, such networks also play an essential role in the socalled "second-order learning" [24] - i.e., raising consciousness towards social, political and economic issues in contemporary agri-food systems - that helps in questioning the logic of the dominant regime and identifying possible alternatives. As a result, these networks also help (re)building collective identities around counter-hegemonic models of sustainable farming that, in turn, bring self-recognition and cognitive justice to farmers engaged in them [25]. For those reasons, we argue, such "intangible" factors as skills, knowledge, access to networks as well as critical consciousness of farmers should be also given space in considerations of "tangible" access to land and other resources in the analyses of sustainability transitions of agri-food systems. In doing so, we follow the recommendation of Darnhofer (p. 26 of [19]) who emphasized the importance of identifying "the strategies employed by various actors to instigate a societal change process" needed for recognizing plausible pathways of sustainability transitions in agri-food systems.

Knowledge, a fundamental intangible asset, is not homogenous. Dating back to the seminal work of [26], knowledge is classified into two types: the codified form, i.e., formal or explicit, and the tacit form. Codified knowledge may be in a relatively lossless way transformed into symbols, and that is why it is usually easily (oftentimes also at no cost) transmitted. Tacit knowledge is not explicit. The transfer of tacit knowledge is strictly dependent on social context because one of its sources is direct contact, cooperation, social proximity. In the case of rural areas, and particularly agriculture, nowadays knowledge becomes the driving force of development [27]. This is a process that we should place in the context of the responses to rural decline connected with the shift of societies from the era of agriculture, through the industrial era, towards a knowledge economy [28].

But how exactly are those intangible aspects of access to land addressed by the actors engaged in experiments with alternative agri-food systems? What can be done to assist (yet to be) farmers in setting up or developing their farms beyond helping secure access to tangible resources such as land, financial capital or machinery? This problem has not received much attention in the literature so far; in this article we want to take a closer look at these issues using the example of three initiatives active in the fields of agroecology, permaculture and organic farming.

Each of the three paradigms that guide the initiatives that will be described here takes a somewhat different approach to farming. The term 'agroecology' is used simultaneously 
to describe a scientific field, a set of agricultural practices and a social movement [29]. As a field of scientific knowledge, agroecology dates back as far as the 1920s [30]. In a simple definition, it "applies ecological concepts and principles to sustainable food systems design and management" (p.2 of [31]). Correspondingly, agroecology-as-practice means that farming is based on "ecological" principles such as managing resources within cycles that resemble natural conditions as much as possible [32] while promoting nonacademic, local knowledge (that is embedded in common context ${ }^{1}$ ) and addressing broader socio-economic problems of sustainable farming. Finally, the social movement that has been built around agroecology in the recent decades combines scientific and practiceoriented agroecological approaches with the recognition of political and cultural contexts in which farming operates-and proposes a radical transformation of the dominant agrifood regimes toward more sustainable alternatives based on food sovereignty, farmers autonomy, cooperativism, support for smallholders or family farms and short food supply chains $[29,33]$.

Of course, in reality the three approaches to agroecology described above mix and overlap; nevertheless, agroecology-as-movement can be seen as a broader and more radical vision of changes in agri-food systems than agroecology-as-science or agroecology-aspractice. The fact that agroecology is subject to many interpretations led some authors to suggest that we should be in fact speaking of multiple 'agroecologies' [34]. It is particularly important to recognize the differences between the politicized understanding of agroecology vis-à-vis the more narrow, technical vision of agroecology that downplays the political issues raised by the agroecological social movement [23]. Therefore, there is a tension between (at least) two competing framings of agroecology—one that generally conforms to the dominant agri-food regimes, and one that opposes them [29]. Although both of these approaches aim to introduce changes in how agri-food systems are functioning, it is clear that from the perspective of socio-technical transitions they differ significantly: the former relies more on incremental modifications of the existing regime while the latter aims at its deeper, structural change.

Permaculture overlaps with agroecology in many ways, and although it is a concept and a movement in itself, it is sometimes represented within the framework of agroecology [24,35]. Quite similarly as in the case of agroecology, the term "permaculture" is also used in various meanings: to describe a movement, a design philosophy and a set of corresponding practices and values [35]. The origins of the concept can be traced back to the works of Mollison and Holmgren [36] who coined the term from the phrase "permanent agriculture", which was subsequently broadened to signify "permanent culture". In consequence, permaculture evolved into "a design methodology for sustainable human habitats that takes inspiration from ways in which natural systems self-organize for resilience and productivity" [37]. The practices that follow from this assumption are based on a set of 12 basic principles oriented on ecosystem mimicry (i.e., making as much use of existing ecosystem relations as possible) and system optimization that are promoted within a widely dispersed, non-institutionalized permaculture movement active around the world ([35,37]. In comparison to agroecology, permaculture principles seem to put more emphasis on broader design thinking, which can be illustrated by such explicitly-formulated principles as "Design from Patterns to Details" or "Use Edges and Value the Marginal" (p. VIII of [38]). Interestingly, permaculture can be also seen as the popular counterpart of agroecology as queries in scientific and non-scientific databases show that agroecology is referred to mostly by academics and policy-makers, while permaculture is much more popular among general audiences [35].

Organic farming represents yet another approach to agriculture that aims to make it more sustainable. It will probably not come as a surprise that organic farming is also a concept that is defined in a variety of ways by various stakeholders. However, in contrast

$1 \quad$ As Beckford and Barker (p. 188 of [39]) stated "local knowledge may be defined as a dynamic and complex bodies of know-how practices and skills that are developed and sustained by peoples/communities with shared histories and experiences". 
to agroecology and permaculture, organic farming is clearly defined by many national and supranational regulations. Moreover, given its longer history and higher profile, it has been more comprehensively scrutinized by scientists who have thus produced a large body of data on its performance [40-42]. In their review of organic farming definitions, Seufert, Ramankutty and Mayerhofer (p.14 of [43]) conclude that organic farming is generally defined as a "chemical-free management system, based on avoiding synthetic inputs, and relying on natural substances instead" (on some occasions, this definition is expanded to include natural processes too). The origins of this approach to farming date back to the 1920s when a group of German farmers began experimenting with the newly-developed biodynamic farming practices that had been inspired by the works of the Austrian philosopher Rudolf Steiner [42]. The term "organic farming" appeared in the literature for the first time some two decades later with reference to the idea of a farm as an "organic whole" that has to be managed holistically [44]). With time (and particularly since the 1990s) organic farming has grown into a set of regulated, certified and market-based set of practices-which is in fact an example of a niche-to-regime translation-and today is not based as much on social movements as agroecology or permaculture [14]. However, it has to be noted that social movements played an essential role in developing and promoting the concept of organic farming worldwide.

To sum up, each of these three approaches to farming intends to introduce changes into the dominant farming regime, albeit in a different way and with different means. Various approaches to agroecology challenge the dominant regime to various extent, but in the broad sense agroecology is a social movement drawing from agroecology-asscience and characterized by political engagement. Permaculture is a global movement too, although not focused as much on direct political change but rather on working its way by popularizing certain values and a design philosophy via less formal and more dispersed networks. At the same time, the concept of agroecology has been evoked mostly by academics and policymakers, while permaculture is much more popular among general audiences. Organic farming, in turn, distinguishes itself by its orientation on markets and regulations without creating a wider social movement or political agenda. In this sense, it might be the least "radical"; nonetheless, it has to be noted that it was perceived as radical in its early days ([24] and in fact can be to some extent considered as a successful niche-to-regime translation. Moreover, today it is still a knowledge-intensive farming model [45] and in recent years there have been some attempts to develop its social, economic or political agenda [14]. While the three approaches to sustainable farming are undergoing constant evolution, we predict that their specificity will be reflected in the activities undertaken by the grassroots initiatives supporting farmers and new entrants in agroecological, permacultural or organic farming.

Clearly, scalability is a crucial issue when the relevance of agroecology, permaculture and organic farming for socio-technical transitions is considered. If these approaches are to have an impact on the sustainability of global agri-food systems, they need to become viable alternatives to conventional farming. What can help understand how this takes place in practice, is the multi-level perspective-an approach developed within transition studies that considers transitions as results of interaction between socio-technical niches, regimes and landscapes [15]. As it was mentioned earlier, niches are protective spaces where alternative farming models can be nurtured without being immediately exposed to competition with the dominant agri-food system practices. Only after reaching some level of 'maturity' — or if appropriate changes at the socio-technical landscape level have occurred that rendered them competitive - can they spread beyond the niche and have some impact on the current socio-technical regime.

Indeed, El-Bilali [6] explicitly mentions agroecology, permaculture and organic farming as examples of socio-technical niches. For this reason, applying standard criteria (e.g., economic performance) to their assessment can lead to concluding that such niche experiments are not promising. Undoubtedly, in many cases niche experiments will fail to produce a viable farming model that could become widely scalable; however, some of them 
might succeed, and this can be only verified within the process of experimentation itself that often consumes significant amounts of time and resources before it can be unequivocally assessed. In this context, the activities of grassroots initiatives engaged in promoting alternative farming models are particularly important because they can help demonstrate whether a given approach to farming is scalable, or not. For this reason, we argue, we need a better understanding of what strategies are adopted by such grassroots initiatives, and how they can be supported in order to provide the necessary demonstration effect.

\section{Methods and Data Sources}

The methodology of this study has been developed in the framework of the Horizon 2020 project "RURALIZATION-The opening of rural areas to renew rural generations, jobs and farms" (Grant Agreement No. 817642) with the purpose of gathering data on promising practices that support access to land for established farmers or new entrants. The method employed in this task is case study. The three case studies are based on a data collection questionnaire prepared by the project partners under the coordination of Terre de Liens (France). The questionnaire was not designed specifically with the framework of transition studies in mind, but it was nonetheless focused on assessing the potential of initiatives supporting access to land for being scaled-up or replicated, and as such it included a number of questions that can provide a response to the research question of this paper. The three case studies are analyzed from the perspective of eight main criteria: (1) basic features, (2) main rural challenge addressed, (3) favored actors, (4) resources employed, (5) innovative elements of the initiative, (6) enabling factors, (7) development barriers. This approach is selected in order to reflect the potential role of such initiatives in socio-technical transitions and allow for a preliminary comparison between the strategies employed by these initiatives (particularly in the context of different approaches to farming they adopt).

In the case of Poland, three initiatives-Agro-Perma-Lab, PermaKultura.Edu.PL and Ecological Folk High School in Grzybów-were chosen as examples of promising practices in supporting access to land (including its non-tangible aspects such as knowledge, skills or networks). The selection of these practices was based on the qualitative assessment of their innovative potential as well as their established position based on the observations of the authors. In other words, we have selected the most promising examples of Polish grassroots initiatives that are explicitly engaged in advancing transitions to alternative farming models, since these initiatives were expected to provide the best insight into the strategies adopted for this purpose. Therefore, the exact models that these initiatives are developing-agroecology, permaculture and organic farming —are not meant to provide an exhaustive overview of alternative farming approaches, but rather serve as examples of how grassroots organizations engage in advancing agri-food transitions and rural development. Polish situation provides a very good opportunity for looking at how non-governmental organizations (NGOs) and informal networks provide grassroots support for sustainability transition in farming since the state is not actively engaged in supporting agroecological or permaculture farmers and has some, but only limited impact on stimulating the development of organic farming that is popularized mostly due to the supra-national support schemes of the EU. Therefore, the results of these case studies will be particularly relevant for other contexts in which socio-technical transitions in agri-food systems are at the moment realized mostly by bottom-up or bottom-bottom practices.

The data collection process was based on desk research performed in close cooperation with the representatives of the three studied initiatives. The questionnaire was first (partly) filled by the researchers themselves on the basis of the data available in secondary sources, i.e., scientific articles, reports, articles in newspapers and websites of the initiatives themselves. In the second step, the representatives of each of the three initiatives were asked to review the data gathered so far by the researchers and asked to provide all information that was not collected during the first stage of data collection. The research team then corrected and completed the content of the questionnaire and, finally, sent the filled questionnaires 
to the representatives of the initiatives for final review. Final remarks were then introduced into the questionnaires and sent back to the representatives of the initiatives for final checks, thus completing the process. The entire process was realized in May-June 2020 and the case studies cover entire relevant periods since the establishment of each of the three practices.

\section{Results}

\subsection{Agro-Perma-Lab}

Agro-Perma-Lab (AP-Lab) is an educational project in the fields of agroecology, permaculture and food sovereignty in Poland. The activities conducted in the project can be grouped into 4 domains: (1) organizing training for leaders, educators and activists in agroecology and permaculture, (2) providing tools for self-assessment of how a particular farm's ecosystem is functioning, (3) coordinating the work on a Polish Declaration of Agroecology and (4) creating a diverse community of people engaged in agroecology, permaculture or the food sovereignty movement that functions as a hub for disseminating knowledge and fostering long-term cooperation between engaged actors.

AP-Lab, run by 12 persons from three organizations (Nyeleni Polska, Ecological High Folk School in Grzybów and PermaKultura.Edu.PL), started in 2019 and in the same year it organized the first training for leaders in agroecology and permaculture; 20 persons from various backgrounds-9 farmers, 6 NGO workers, 4 food cooperative members and a lawyer-took part in the training that lasted 10 days and was realized at a farm in Grzybów (a village in Mazowieckie Voivodship, central Poland). The participants were tutored by 20 international facilitators on the basis of a participative approach of peer-to-peer learning called 'Diálogo de Saberes' that had been adapted from the methodology developed by La Via Campesina, an international network active in the field of rural development [46]. The goal of the training was to train local leaders, activists and educators in developing competences that would allow them to further promote agroecology and permaculture in their respective contexts. For this reason, the curriculum placed significant emphasis not only on agroecological topics but also on personal competences related to communication, leadership and co-organization of bottom-up initiatives.

Apart from 'educating the educators' in person, AP-Lab also provides a self-assessment tool that can be used by farmers or new entrants to diagnose and design a farm in close connection with the ecosystem in which it is functioning. The self-assessment tool for farms was prepared on the basis of three exemplary farms from Poland studied by the AP-Lab team as well as the knowledge and experience of its members. It is a 32-page document (Figure 1), freely available from the project's website [47], that explains the methodology of the self-assessment and provides three examples of such an assessment of selected exemplary farms.

The approach of AP-Lab to agroecology is based on the agroecology-as-movement approach. As a result, the curriculum of the training for leaders includes e.g., classes related to political strategies of advancing sustainability transitions in agri-food systems. Moreover, AP-Lab coordinates the work on preparing the Polish Declaration of Agroecology that is going to outline the vision of agroecological farming in Poland. Although this will not be the first document of its type in the world, the AP-Lab intends to adapt it to the context of farming challenges in Poland. The declaration is created in order to promote the holistic character of agroecology that includes not only agricultural and environmental aspects but also political, socio-economic or cultural postulates within the transitions framework.

Finally, the initiative puts an emphasis on creating a vibrant community of people from various backgrounds (with a focus on farmers) engaged in agroecology, permaculture and food sovereignty movements. The AP-Lab intends to function as a hub for disseminating knowledge and experiences that can build upon dialogue and solidarity between its members. This is realized mainly, but not exclusively by providing the training for leaders in agroecology and permaculture, participating and co-organizing events (such as the II Food Sovereignty Forum that took place in Warsaw in early 2020), or running a website and social media communication pages. 


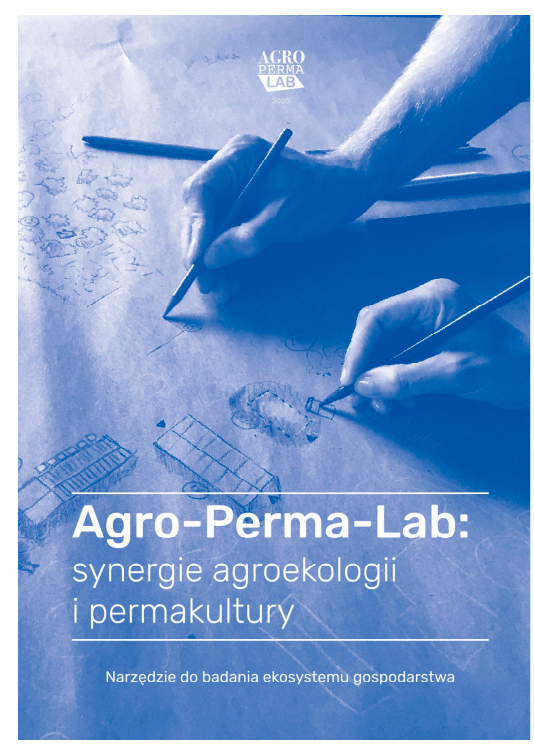

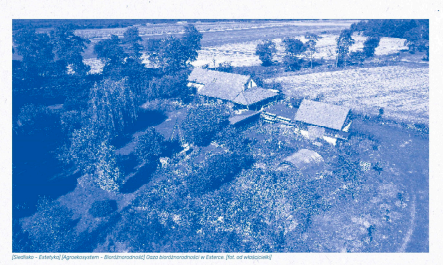

NARZĘDZIE DO BADANIA EKOSYSTEMU GOSPODARSTWA

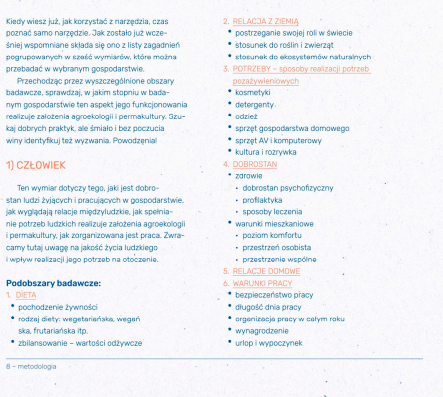

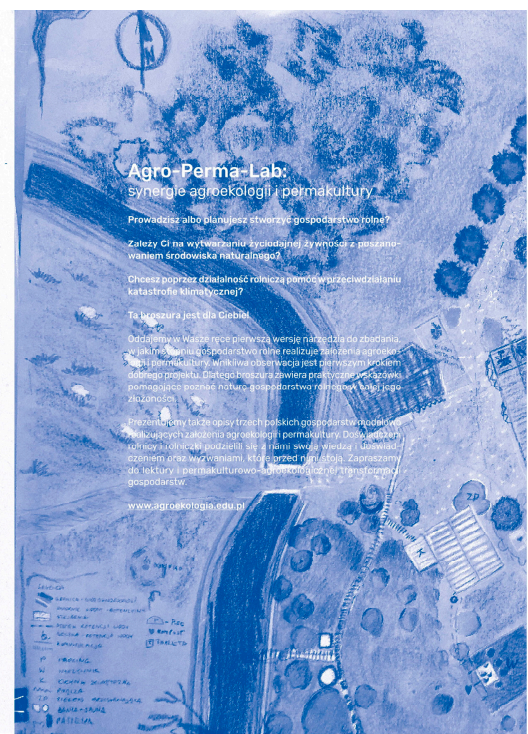

Figure 1. Excerpts from the self-assessment tool for farms prepared by Agro-Perma-Lab (image source: Łukowska, 2020).

The organizers of the practice identify four enabling factors that were crucial in establishing the practice. Firstly, the initiative received support from strategic partners both from Poland and abroad. The relations already established with key partners-Schola Campesina (Italy), Landworkers Alliance (UK), Ecological Folk High School in Grzybów (Poland) and PermaKultura.Edu.PL (Poland)—significantly helped in setting up the project, since when the idea was proposed, many fundamental resources were already at hand. Secondly, the participants and supervisors of the training of leaders were coming from diverse backgrounds. The idea behind the training was to bring together people with various perspectives; for instance, a scientist and an established farmer who perceive issues such as climate change from their unique perspectives that can be seen as complementary. Thirdly, the initiative was building upon an existing network of cooperation and trust that significantly facilitated the mobilization and cooperation within the group that manages the practice. The fourth enabling factor was that the training of leaders was organized "on the ground", for 10 days at a real farm, which provided sufficient time both for learning and extra-curricular activities that, in turn, led to establishing a wide network of actors engaged in agroecology and permaculture.

The organizers also identified four development barriers of the initiative. Firstly, a tension between the need for leadership and the horizontal structure of the organization behind the AP-Lab. This is perceived as the greatest challenge of the project, since on the one hand without leadership the project can lose momentum, but on the other hand strong leadership sparks tensions within the group that organizes the practice. Secondly, the organizers had difficulty in adapting the internationally-focused curriculum of the training of leaders to the context of Poland. The adaptation of very diverse and often complicated international phenomena taken up by the curriculum (originally devised by Schola Campesina) to the training organized in Poland is a challenging task. For instance, issues around gender inequalities are different in the Global South-which is the focus of many international curricula - and in Poland. This should not be understated, and the organizers of the practice emphasize that it is best to have an interdisciplinary team of people working on the translation and adaptation of the curriculum into local/national contexts. Thirdly, there is a dissonance in the perception of volunteering and paid work performed by the group members. Some people were engaged in the practice as volunteers and, in some cases, it resulted in tensions between the remuneration of work of some engaged persons against no financial remuneration of others. Finally, the organizers believe that the practice could have reached out more to grassroots rural organizations from non-activist backgrounds. Although AP-Lab puts emphasis on diversity, it faced 
difficulty in reaching out to rural organizations of farmers who are not familiar with the topics of agroecology or permaculture. The team recognizes a need to communicate with such actors in an effective way.

\subsection{PermaKultura.Edu.PL}

PermaKultura.Edu.PL is an educational and networking initiative active in the field of permaculture. The initiative started in 2015 and is managed by 3 persons (one leader and two part-time supporters) who are active both "on the ground" and in the digital sphere. In general, the leader of the practice follows the model of an "itinerant teacher" [35], who in this case is an independent educator popularizing permaculture knowledge through on-farm training rather than in one, centralized facility.

The main activities of PermaKultura.Edu.PL include (1) organizing workshops: on permaculture as well as on the preservation of traditional plant species in farming, (2) on-line activity that includes webinars and video lectures on permaculture as well as running social media channels and a website (that includes among other things a map of permaculture initiatives in Poland) and (3) translating into Polish and publishing the most important permaculture-related books.

The workshops organized by PermaKultura.Edu.PL usually last a few consecutive days and cover a wide range of topics: designing a farm's agro-eco-system, selecting appropriate species for cultivation, animating communities organized around food systems, managing the flows of water or nutrients at the farm, introducing sustainable farming techniques, or collecting and exchanging seeds. Usually, the curriculum of the workshops includes also wider issues such as food sovereignty or political engagement in the context of agri-food systems; however, the focus lies clearly in practical skills and knowledge, as well as networking between the participants during the time spent together at the farm. The workshops were first organized in 2014 and since then they have attracted approximately 500 participants. The second type of workshop organized by PermaKultura.Edu.PL covers the topic of the preservation of native plant species and fostering biodiversity in the practices of permaculture. These began in 2019 and so far have been attended by approximately 300 participants. In total, the workshops of both types took place at approximately 40 farms in Poland.

On-farm workshops are complemented by several activities in the digital sphere: webinars and video lectures on permaculture as well as a website and a Facebook fan page. The webinars and video lectures offer a more or less complete introduction to permaculture while the website and Facebook fan page are used as a means of their distribution and, additionally, work as a tool for fostering the creation of a community around permaculture in Poland. To this end, the website provides an extensive map of permacultural farms or gardens in Poland (ca. 100 places as of 2020) with contact data of their organizers (Figure 2). Community building is also performed via the "Club of scythe mowers" (about 300 persons with varying levels of engagement as of 2020) organized both on-line and on-the-ground with the purpose of exchanging skills and knowledge related to traditional methods of mowing.

Finally, the goal of promoting permaculture in Poland is also realized by adopting a strategy of translating and publishing permaculture-related books. So far, 3 books have been published and a further one is currently in the process of publication. The books are translated and published on the basis of crowdfunding campaigns whereby one can purchase the book before its publication and receive it after enough funds for the process have been collected. For each of the three books published so far, 300-350 people joined the crowdfunding pre-purchase and about 2000 people bought the books afterward. A similar crowdfunding strategy based on issuing bonds that can be later exchanged for food produce, participation in training or even cash is adopted to develop a farm in South-East Poland that is going to serve as a headquarters of the initiative. 


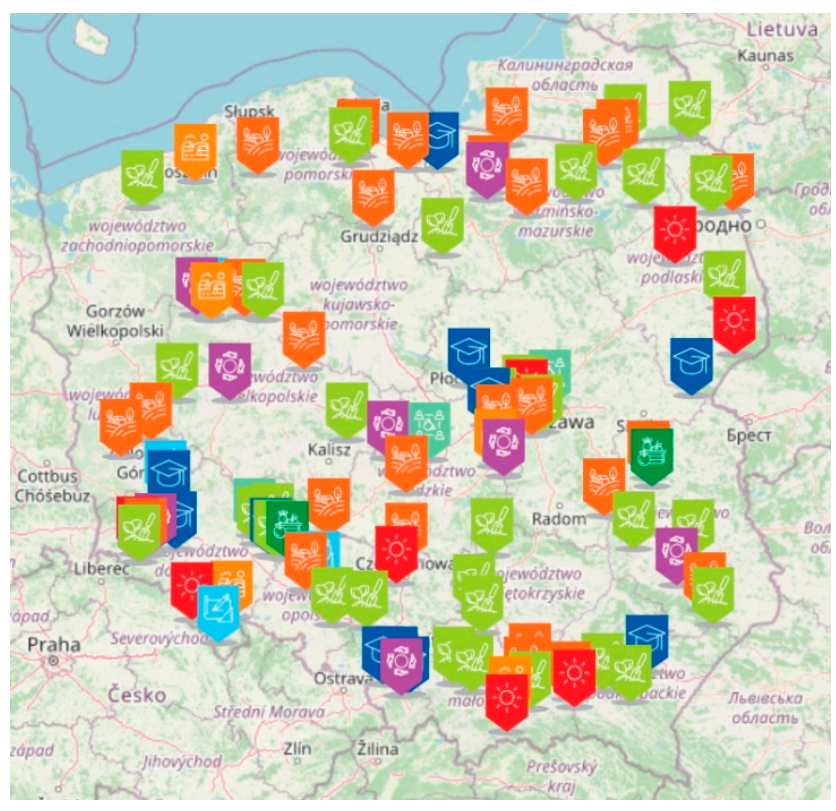

Figure 2. Map of permaculture initiatives in Poland developed by PermaKultura.Edu.PL (image source: https: / / mapa.permakultura.edu.pl, accessed on 13 November 2020).

The organizers identified the two most important factors that enabled the success of the initiative. The first one is the perseverance in the initial period of the practice. The leader of the practice was able to build a community around permaculture that later gave the practice the momentum needed to go on. This has been achieved mostly by continuous work on the ground (organizing workshops at farms) that gradually led to the wider recognition of the practice in Poland. Secondly: good timing. The initiative was established at a moment when many people became interested in permaculture but still did not know a lot about it. Thus, there was (and still is) a demand for educational activities of this type.

The development barriers reported by the organizers are (1) limited funds and (2) no headquarters farm that could operate throughout the entire year. Currently, the workshops are organized only in the summer, since this is when farms at which workshops are organized are active. If the practice had an all-year educational facility, some activities could be also performed in the winter months.

\subsection{Ecological Folk High School in Grzybów}

Ecological Folk High School in Grzybów (EFHSiG) is an educational facility located at a farm in the village of Grzybów (central Poland) run by the 'Ziarno' Ecological-Cultural Association. ${ }^{2}$ The inspiration to create an Ecological Folk High School in Grzybów came from the ideas of N. F. S. Grundtvig who had come up with the idea of folk high schools of farming in 19th-century Denmark. The EFHSiG began its operation in 2001 when it organized a 3-week course on ecology and local culture for women from local communities of Grzybów and surrounding areas. Since then, EFHSiG has conducted over 50 short (5-10 weeks) courses on organic farming knowledge, skills and culture-mostly in rural areas of Poland (some of which took place at the farm in Grzybów). The initial success of EFHSiG led to recognition by the Velux Foundation from Denmark that decided to support the school with a grant for organizing two editions of full-time, 2-year courses on organic farming. The funding was granted specifically because the practice was run as a folk high school (and thus was considered important for the mission of the Danish Velux foundation). The grant covered two editions of the course, but also the construction of a building at the farm designed specifically to serve an educational function.

2 For the website of the initiative, see: http:/ / www.eul.grzybow.pl/english, accessed on 13 November 2020. 
Today, the main activity of the EFHSiG is the organization of full-time courses on organic farming. The first course began in 2015, and the next followed in 2016. These courses offer the most comprehensive opportunity for education in organic farming in Poland, and include about 100 days of classes in Grzybów as well as 14 months of internships at selected organic farms in other parts of Poland. The main target group of the courses are young people interested in organic farming. The curriculum of the course is based on the curricula used in regular farming schools in Poland but it includes not only (organic) farming knowledge and skill development (Figure 3) but also practical classes on personal development, English language, leadership and communication skills as well as cultural competences (e.g., every participant is encouraged to learn at least one traditional song). The course has no formal examination procedure, but the participants can, and often do, pass the official, external exam confirming the competences of a farmer in Poland. So far, 33 persons completed the first two editions of the course and 20 of them are now active in farming or farming-related education or activism. Currently, the third edition of the course, which began in 2018, is in progress thanks to a successful crowdfunding campaign organized by its students. The plans for the fourth edition are uncertain since the school is not sure whether it will receive a grant covering the costs of its organization.

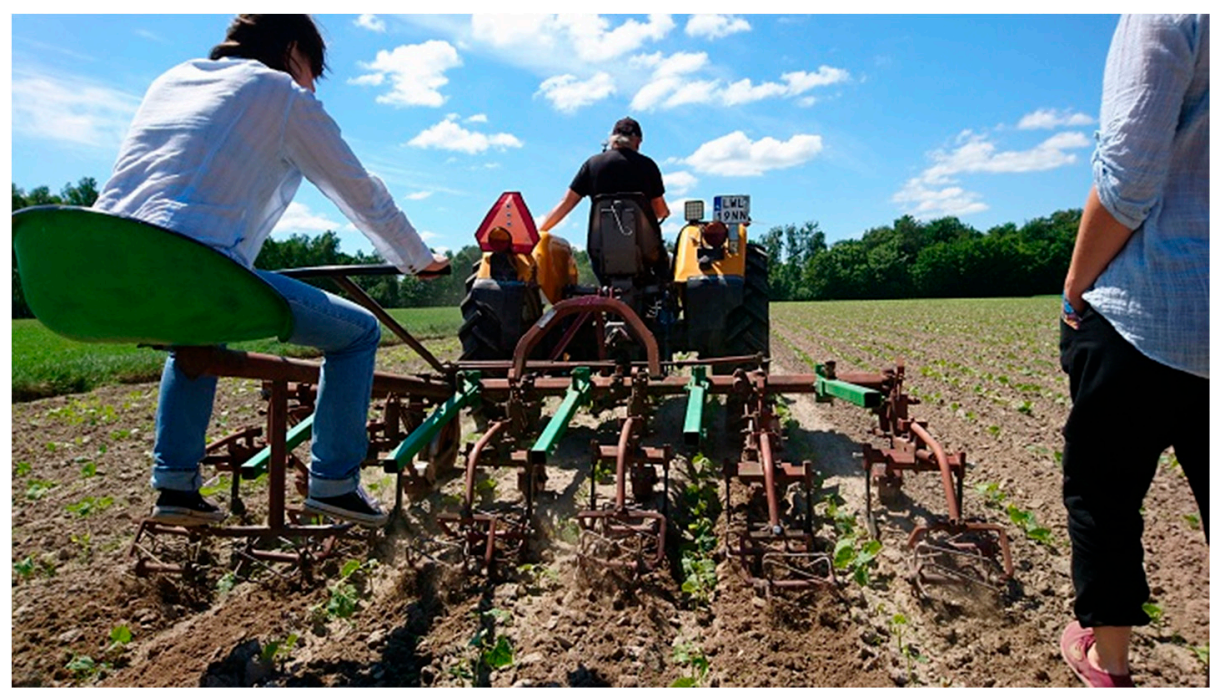

Figure 3. Practical classes at the Ecological Folk High School in Grzybów (image source: EFHSiG; http: / / www.eul.grzybow.pl/aktualnosci/134-zjazd-na-lubelszczyznie, accessed on 13 November 2020).

The most important factor that helped establish the initiative was identified by the organizers as the eagerness of young and middle-aged people to join a course. The organizers believe that the disillusionment with modern, hyper-consumptive lifestyles among new generations helped them reach out to people who had already been looking around for ways to enter organic farming. Moreover, climate change and ecological crises led to a reported feeling of urgency among the participants of the course, who were thus even more eager to engage in organic farming (that is supposed to alleviate the problem). At the same time, the organizers believe that their high level of commitment towards their vision significantly helped to overcome the barriers they met on the way.

The development barriers were-except for collecting funds-mostly a result of no precedent of folk high schools in Poland which meant that the organizers had no example to refer to when establishing the school. Finding the teachers or adapting the curriculum was challenging in such circumstances. Moreover, EFHSiG was generally not treated as an official school for farmers' education in the domestic regulations, which hampered the official recognition of the competences gained there by the students (although eventually they were allowed to take the official Polish exam verifying farming competences). 


\section{Discussion}

The analysis of the three initiatives shows that although all of them are focused on promoting sustainable farming alternatives in Poland, each follows a slightly different model of functioning rooted in the farming models they promote. What distinguishes Agro-Perma-Lab from the other two practices is the emphasis it places on the political aspects of sustainability transitions of agri-food systems, which is exemplified in particular by their work on the Polish Declaration of Agroecology and a coalition of several existing NGOs and informal networks engaged in running the practice-which reflects the global strategies of actors operating within the agroecology-as-movement framework. Taking a different approach, PermaKultura.Edu.PL is focusing on strategies characteristic for the global permaculture movement-spreading ethical values and a 'practical philosophy' via a dispersed network of 'itinerant teachers' who slowly but consistently build up informal communities around the vision of permaculture in the regions where they operate. For this reason, strategies adopted by PermaKultura.Edu.PL are more low-cost, often based on crowdfunding and include a high number of workshops conducted at individual farms in all parts of Poland. Ecological Folk High School in Grzybów has, in turn, adopted a more formalized although still informal, education model rooted in the Danish concept of folk high schools adapted for teaching organic farming in Poland. This initiative is linked to the system of farming education in Poland, is managed by an NGO, and is based on exogenous resources to a larger extent than the other two.

Correspondingly, each of the three initiatives seems to be tackling a slightly different rural challenge, favoring different types of actor and employing various types of resources (Table 1). AP-Lab aims at building a network of local/regional leaders, activists and educators, who possess a set of skills needed to further advance agroecology and permaculture in their contexts. This initiative is based partly on endogenous (knowledge, networks, funds) and partly on exogenous resources (also knowledge and funds, as well as methodology). PermaKultura.Edu.PL, based mostly on endogenous resources, addresses final target groups more directly by teaching permaculture methods and philosophy to individuals or groups of new entrants into farming, who in both cases are using that knowledge mostly for their own purposes (and are mostly smallholders). EFHSiG also targets new entrants, but with more connection to the formalized education system in which organic farming is a regulated, usually certified, set of practices. What has to be noted too is that the school is clearly transgressing the concept of organic farming by including cultural or socioeconomic topics in the curriculum of the course on organic farming. In doing so, EFHSiG reflects a wider shift in organic farming towards a more comprehensive approach going beyond 'technical' regulations of what types of inputs should be used at the farm [14].

Table 1. Assessment of the three initiatives against selected criteria.

\begin{tabular}{|c|c|c|c|}
\hline & Agro-Perma-Lab & PermaKultura.Edu.PL & EFHSiG \\
\hline Basic features & $\begin{array}{c}\text { An educational and } \\
\text { networking project } \\
\text { coordinated by several } \\
\text { non-governmental } \\
\text { organizations (NGOs) and } \\
\text { informal networks working in } \\
\text { cooperation }\end{array}$ & $\begin{array}{l}\text { A low-cost educational and } \\
\text { networking initiative led by } \\
\text { an "itinerant" permaculture } \\
\text { teacher }\end{array}$ & $\begin{array}{l}\text { A non-formal educational } \\
\text { initiative rooted in the Danish } \\
\text { model of folk high schools run } \\
\text { by an NGO }\end{array}$ \\
\hline $\begin{array}{l}\text { Main rural challenge } \\
\text { addressed }\end{array}$ & $\begin{array}{l}\text { Lack of leaders and networks } \\
\text { that could further disseminate } \\
\text { agroecology and } \\
\text { permaculture }\end{array}$ & $\begin{array}{c}\text { Lack of skills, knowledge and } \\
\text { networks }\end{array}$ & $\begin{array}{l}\text { Entry barriers to organic } \\
\text { farming }\end{array}$ \\
\hline Favored actors & $\begin{array}{l}\text { Local/regional leaders; } \\
\text { informal networks of activists, } \\
\text { educators and farmers }\end{array}$ & $\begin{array}{l}\text { New entrants into farming; } \\
\text { smallholders }\end{array}$ & $\begin{array}{l}\text { New entrants interested in } \\
\text { organic farming }\end{array}$ \\
\hline
\end{tabular}


Table 1. Cont.

\begin{tabular}{cccc}
\hline Agro-Perma-Lab & PermaKultura.Edu.PL & EFHSiG \\
\hline Employed resources & $\begin{array}{c}\text { Endogenous (labor, networks, } \\
\text { funds) and exogenous } \\
\text { (knowledge, methodology, } \\
\text { funds) }\end{array}$ & $\begin{array}{c}\text { Mostly endogenous (labor, } \\
\text { networks, funds, knowledge) }\end{array}$ & $\begin{array}{c}\text { Endogenous (knowledge, } \\
\text { labor, networks, funds) and } \\
\text { exogenous (funds, methods) }\end{array}$ \\
\hline $\begin{array}{c}\text { Innovative elements of the } \\
\text { initiative }\end{array}$ & $\begin{array}{c}\text { Working at the "meta-level", } \\
\text { i.e., "educating the educators", } \\
\text { thus creating a multiplier } \\
\text { effect }\end{array}$ & $\begin{array}{c}\text { Following the model of an } \\
\text { "itinerary" permaculture } \\
\text { teacher }\end{array}$ & $\begin{array}{c}\text { Adapting the concept of folk } \\
\text { high schools to Polish } \\
\text { conditions }\end{array}$ \\
\hline
\end{tabular}

(1) Support from strategic partners both from Poland and abroad;

(2) diverse backgrounds of participants and supervisors;

Enabling factors

(3) building upon an existing network of cooperation and trust;

(4) organizing the training of leaders at a real farm with sufficient time for networking
(1) Perseverance in the initial period needed for establishing a community around permaculture;

(2) good timing of establishing (a growing demand for education in permaculture)
(1) Eagerness of young and middle-aged people to engage in organic farming;

(2) commitment of the organizers

(1) tension between leadership and non-hierarchical structure;

(2) difficulties in adapting the internationally-oriented training curriculum to the Polish context;

(3) tensions between volunteering and paid work perception;

(4) reaching out to regular farmers.
(1) Difficulty in raising funds;

(2) no headquarters that would enable organizing courses throughout the year
(1) No precedent of folk high schools in Poland;

(2) raising funds;

(3) weak connection with Polish formal education system

The potential for rural regeneration brought by such initiatives lies in their direct and indirect impacts on rural areas. Directly, these initiatives develop human and social capital, promote farming as a career choice among new generations, improve public perception of farmers (and peasants), repoliticize the problems of agri-food systems as well as retain and spread skills and knowledge related to sustainable farming. Indirectly, these impacts might contribute to rural regeneration brought about by generational renewal, proliferation of sustainably-managed farms, establishment of alternative food networks, or establishing appropriate regulations resulting from political pressure. Certainly, each of the case studies shows an element of innovation in the Polish food systems landscape: AP-Lab works as a school of leaders in the context of farming, PermaKultura.Edu.PL brings the model of itinerant teachers to Polish farmers, and EFHSiG shows that the Danish model of folk high schools can be well adapted to organizing comprehensive courses on organic farming in Poland.

It is difficult to assess the exact potential of these initiatives for socio-technical transitions in agri-food systems. Niches can, but do not have to translate into changes in the dominant regimes. When the classification of innovation diffusion pathways developed 
within the multi-level perspective is considered [48], it becomes clear that the strategies employed by these initiatives are based mostly on replication and upscaling, and none of them is targeted at niche-to-regime translation. Some action aimed at the latter was undertaken by the EFHSiG which managed to have its organic farming course recognized by the authorities, as their graduates were allowed to take part in the official examination confirming the qualifications of a farmer in Poland. However, this arrangement is not reflected in regulations that would, for instance, officially recognize the EFHSiG course as an element of farmers' formal education pathway; nor has it been incorporated into other educational curricula. Therefore, the impacts of these initiatives on the dominant regimes are expected to be limited as long as they focus on replication and upscaling, i.e., strategies of niche development.

It has to be noted, however, that strategies aimed at replication and upscaling have also been recognized as important aspects of socio-technical transitions. While providing vocational education by the EFHSiG seems to be an obvious prerequisite of advancing sustainability transitions [8], building political capacity, as performed by AP-Lab, and popularizing values, as PermaKultura.Edu.PL does, are also seen as crucial for niches to be eventually able to influence the dominant regimes [19]. Supporting peer network creation and bolstering farmers' self-recognition as well as critical consciousness are considered as important elements of that process too $[23,25,33]$. Therefore, while their impacts should be scrutinized in more detail in further research, the strategies themselves adopted by the analyzed initiatives seem to be well adjusted to both the general frameworks in which they operate - agroecology, permaculture and organic farming — as well as the logic behind advancing sustainability transitions in agri-food systems.

\section{Conclusions}

This article analyzed three case studies of grassroots initiatives from Poland to show how supporting farmers in gaining access to land is complemented with other, less tangible factors such as skills and knowledge development, networking, creating political capacity or building self-recognition and critical consciousness among farmers-particularly new entrants into farming - in order to advance socio-technical transitions to more sustainable models of agriculture: agroecology, permaculture and organic farming.

The examined initiatives intend to advance such transitions in a variety of ways. On-farm workshops, digital educational materials, publication of books by crowdfunding, full-time organic farming courses or training for leaders in agroecology and permaculture are some of the strategies employed by these grassroots initiatives. The strategies used by each of them seem to reflect the differences between concepts they are rooted in by placing emphasis on those aspects that can be considered distinguishable for agroecology, permaculture and organic farming. Of course, the division between them is not absolutely clear, but rather blurred as they overlap to some extent.

At the same time, there are clear commonalities between the three initiatives. Firstly, all of them are concentrating on improving skills and knowledge-including both explicit and tacit knowledge- of farmers, new entrants as well as farming-related activists and educators in Poland. They also create opportunities for networking, self-recognition and the development of critical consciousness that result from framing farming as a political issue. These initiatives also tried to facilitate knowledge exchanges by establishing multiactor knowledge networks, which are perceived by [49] as a pillar of the agriculture transformation into more sustainable models. Secondly, they are all based on the logic of grassroots, horizontal networks that range from local to regional, national or even international scales. This approach has been identified as an important mechanism behind the propagation of innovations in socio-technical transitions [50]. From this perspective, the fact that the three initiatives partly overlap in terms of content, employed frameworks and managing actors reflects the process of a niche development that is needed for the innovative elements of these initiatives to translate to other, wider contexts. 
The data gathered within this study do not allow for a direct evaluation of the impacts of these initiatives. Although some data on the direct effects of selected activities are known (e.g., the number of participants in the course on organic farming or the training of leaders in agroecology and permaculture), it is difficult to answer the question of how exactly this will translate into rural regeneration and advancing socio-technical transitions in agri-food systems. Each of these initiatives is so far operating in a niche, as of now adopting strategies aimed mostly at niche development (replication and upscaling), that can only potentially grow to such an extent that would have an impact on the dominant regimes of agri-food systems.

This might be partly related to the fact that among the sources of knowledge of Polish farmers, NGOs are one of the least preferred and are perceived as less important than those that are spatially and socially more available: family or neighbors [51]. Other research confirms that fact; Wójcik, Jeziorska-Biel and Czapiewski [52] stated that contacts and direct contact with the nearest family, neighbors or representatives of various institutions remain the most important sources of knowledge for farmers. Agricultural knowledge is often transferred through farmers' social interactions (see e.g., Conley, Udry, 2001; Saint Ville et al., 2016) $[53,54]$ thanks to a common context. Therefore, grassroots initiatives should pay attention to strategies of communication beyond their community of practice, preferably trying to build upon common knowledge that both they and the actors they want to influence are familiar with [24]. This should be recognized both in the research on the impacts of grassroots initiatives as well as in the strategies employed by them.

Rural regeneration requires action on many levels and in many areas. However, in creating the conditions for rural development, including access to land and other resources, a key role is also played by public sector institutions responsible for, among other things, regulations, financial support, etc. It seems that addressing the challenges faced by rural areas today requires to a large extent a completely new, 'revolutionary' approach. The activities of grassroots initiatives seem to have the potential needed to provide such approaches. As we argued earlier, providing support for such grassroots initiatives could be potentially beneficial for rural regeneration on the one hand, and for verifying the viability of alternative farming models on the other. This is certainly not an easy task, but public authorities do have access to tools to organize this process by, e.g., supporting various intermediaries that are considered key in spreading innovations from niches into regimes [55]. It is important that this transfer takes the interests of many actors into consideration: it must show new paths of development on the one hand, but at the same time respond to the needs of farmers and new entrants into farming on the other.

From the perspective of the grassroots initiatives, it might be important to seek a balance between their radical and reforming elements, which is considered crucial for the possibility of niche development to be translated into changes in socio-technical regimes [24]. Clearly, this poses a risk of watering down the practices when they are adopted more widely; however, in the opposite case the innovations proposed by the initiatives are prone to be considered too radical to become incorporated into the regime. This is a dilemma that every grassroots initiative has to face. Some initiatives will probably choose more radical pathways; but it has to be remembered that this might also constitute a logical choice for those initiatives that aim not specifically at advancing socio-technical transitions, but rather at their self-oriented goals (e.g., community resilience).

All in all, it seems that the ways in which Polish grassroots initiatives support farmers and new entrants can be replicated in other contexts too. The strategies of 'educating the educators', thus creating a multiplier effect, working along the lines of 'itinerary permaculture teachers' (active in many parts of the world) or establishing a folk high school linked to the formal educational system (the idea of which was itself imported from Denmark) show the potential to be adapted elsewhere. But to what extent will they be able to reach farmers and influence their practices? More research on the efficiency and adaptability of particular strategies could be helpful in supporting the strategic decisions of actors engaged in sustainability transitions in agri-food systems. What is especially 
important in designing further studies is to examine not only the strategies adopted by the initiatives but also the (direct and indirect) effects they have on rural regeneration and sustainability transitions.

Finally, we recognize that the strategies described in this paper do not cover the entirety of resources that farmers and new entrants need to thrive. Access to markets, tools, labor, financial capital and, of course, land is essential for most types of farming initiatives. Creating opportunities for just and inclusive access to these resources-by different actors, not only NGOs or informal networks-is going to make socio-technical transitions to sustainable agri-food systems much smoother. We hope that this study has helped shed light on how such access is and could be supported in practice.

Author Contributions: Conceptualization: R.S., S.D., K.J., A.R.; Methodology: R.S. (on the basis of the methodology prepared by Terre de Liens);Validation: S.D., K.J., A.R.; Formal Analysis: R.S.; Investigation: R.S.; Resources: S.D.; Data Curation: R.S.; Writing-Original Draft Preparation: R.S.; Writing-Review and Editing: R.S., S.D., K.J., A.R.; Supervision: S.D., K.J., A.R.; Project Administration: S.D.; Funding Acquisition, S.D., K.J., A.R. All authors have read and agreed to the published version of the manuscript.

Funding: This paper has been produced in the framework of the RURALIZATION project, which has received funding from the European Union's Horizon 2020 research and innovation programme under grant agreement no. 817642. The paper reflects only the authors' view and the European Commission is not responsible for any use that may be made of the information it contains.

Institutional Review Board Statement: Not applicable.

Informed Consent Statement: Not applicable.

Data Availability Statement: The data presented in this study are available on request from the corresponding author. The data are not publicly available due to privacy restrictions.

Acknowledgments: The Authors would like to acknowledge the role of Terre de Liens (France) in developing the methodology of the study as well as the role of Agro-Perma-Lab, PermaKultura.Edu.PL and the Ecological Folk High School in Grzybów in providing and reviewing data gathered within the case studies.

Conflicts of Interest: The authors declare no conflict of interest.

\section{References}

1. Springmann, M.; Clark, M.; Mason-D'Croz, D.; Wiebe, K.; Bodirsky, B.L.; Lassaletta, L.; De Vries, W.; Vermeulen, S.J.; Herrero, M.; Carlson, K.M.; et al. Options for keeping the food system within environmental limits. Nature 2018, 562, 519-525. [CrossRef]

2. Poore, J.; Nemecek, T. Reducing food's environmental impacts through producers and consumers. Science 2018, 360, 987-992. [CrossRef] [PubMed]

3. Bowles, N.; Alexander, S.; Hadjikakou, M. The livestock sector and planetary boundaries: A 'limits to growth' perspective with dietary implications. Ecol. Econ. 2019, 160, 128-136. [CrossRef]

4. Loboguerrero, A.M.; Thornton, P.; Wadsworth, J.; Campbell, B.M.; Herrero, M.; Mason-D'Croz, D.; Dinesh, D.; Huyer, S.; Jarvis, A.; Millan, A.; et al. Perspective article: Actions to reconfigure food systems. Glob. Food Secur. 2020, 26, 100432. [CrossRef] [PubMed]

5. Vermunt, D.; Negro, S.; Van Laerhoven, F.; Verweij, P.; Hekkert, M. Sustainability transitions in the agri-food sector: How ecology affects transition dynamics. Environ. Innov. Soc. Transit. 2020, 36, 236-249. [CrossRef]

6. El Bilali, H. Research on agro-food sustainability transitions: A systematic review of research themes and an analysis of research gaps. J. Clean. Prod. 2019, 221, 353-364. [CrossRef]

7. Rossi, A. Beyond Food Provisioning: The Transformative Potential of Grassroots Innovation around Food. Agriculture 2017, 7, 6. [CrossRef]

8. Carlisle, L.; De Wit, M.M.; DeLonge, M.S.; Iles, A.; Calo, A.; Getz, C.; Ory, J.; Munden-Dixon, K.; Galt, R.; Melone, B.; et al. Transitioning to Sustainable Agriculture Requires Growing and Sustaining an Ecologically Skilled Workforce. Front. Sustain. Food Syst. 2019, 3, 1-8. [CrossRef]

9. Rioufol, V.; de Quijano, M.D. Europe's New Farmers. Innovative Ways to Enter Farming and Access Land. European Access to Land Network. 2018. Available online: https:/ / www.accesstoland.eu/IMG/pdf/a21_newentrants_handbook.pdf (accessed on 13 November 2020).

10. Pindado, E.; Sánchez, M.; Verstegen, J.A.; Lans, T. Searching for the entrepreneurs among new entrants in European Agriculture: The role of human and social capital. Land Use Policy 2018, 77, 19-30. [CrossRef] 
11. Floriańczyk, Z.; Janc, K.; Czapiewski, K. The importance and diffusion of knowledge in the agricultural sector: The Polish experiences. Geogr. Pol. 2012, 85, 45-56. [CrossRef]

12. Ulbrich, R.; Pahl-Wostl, C. The German Permaculture Community from a Community of Practice Perspective. Sustainability 2019, 11, 1241. [CrossRef]

13. Krebs, J.; Bach, S. Permaculture-Scientific Evidence of Principles for the Agroecological Design of Farming Systems. Sustainability 2018, 10, 3218. [CrossRef]

14. Migliorini, P.; Wezel, A. Converging and diverging principles and practices of organic agriculture regulations and agroecology. A review. Agron. Sustain. Dev. 2017, 37, 63. [CrossRef]

15. Geels, F.W. Socio-technical transitions to sustainability: A review of criticisms and elaborations of the Multi-Level Perspective. Curr. Opin. Environ. Sustain. 2019, 39, 187-201. [CrossRef]

16. Loorbach, D.; Frantzeskaki, N.; Avelino, F. Sustainability Transitions Research: Transforming Science and Practice for Societal Change. Annu. Rev. Environ. Resour. 2017, 42, 599-626. [CrossRef]

17. Sengers, F.; Wieczorek, A.J.; Raven, R. Experimenting for sustainability transitions: A systematic literature review. Technol. Forecast. Soc. Chang. 2019, 145, 153-164. [CrossRef]

18. Hossain, M. Grassroots innovation: A systematic review of two decades of research. J. Clean. Prod. 2016, 137, 973-981. [CrossRef]

19. Darnhofer, I. Socio-technical transitions in farming: Key concepts. In Transition Pathways towards Sustainability in Agriculture: Case Studies from Europe; Sutherland, L.A., Darnhofer, I., Wilson, G.A., Zagata, L., Eds.; CAB International: Wallingford, CT, USA, 2015; pp. 17-31. [CrossRef]

20. Rodrigo, J.; Rioufol, V. Supporting Access to Land for Farmers in Europe. Experiences and Potential of Local Authorities. European Access to Land Network: n.d. 2017. Available online: https:/ /www.accesstoland.eu/IMG/pdf/a21_handbook_local_authorities.pdf (accessed on 13 November 2020).

21. Volz, P.; Harries, R.; Riouful, V.; Bîrharla, B.; Parot, J.; Iserte, M. Access to Land and Community Supported Agriculture. Stories from Europe. European Access to Land Network \& URGENCI: n.d. 2017. Available online: https://urgenci.net/wp-content/uploads/ 2017/06/A2L_Pages.pdf (accessed on 13 November 2020).

22. EIP-AGRI. EIP-AGRI Focus Group -New Entrants into Farming: Lessons to Foster Innovation and Entrepreneurship. 2016. Available online: https:/ / ec.europa.eu/eip/agriculture/sites/agri-eip/files/eip-agri_fg_new_entrants_final_report_2016_en.pdf (accessed on 13 November 2020).

23. Anderson, C.R.; Maughan, C.; Pimbert, M.P. Transformative agroecology learning in Europe: Building consciousness, skills and collective capacity for food sovereignty. Agric. Hum. Values 2019, 36, 531-547. [CrossRef]

24. Maye, D. Examining Innovation for Sustainability from the Bottom Up: An Analysis of the Permaculture Community in England. Sociol. Rural. 2016, 58, 331-350. [CrossRef]

25. Coolsaet, B. Towards an agroecology of knowledges: Recognition, cognitive justice and farmers' autonomy in France. J. Rural. Stud. 2016, 47, 165-171. [CrossRef]

26. Polanyi, M. The Tacit Dimension; Routledge: London, UK, 1966.

27. Cooke, P.; Leydesdorff, L. Regional Development in the Knowledge-Based Economy: The Construction of Advantage. J. Technol. Transf. 2005, 31, 5-15. [CrossRef]

28. Li, Y.; Westlund, H.; Liu, Y. Why some rural areas decline while some others not: An overview of rural evolution in the world. J. Rural. Stud. 2019, 68, 135-143. [CrossRef]

29. Levidow, L.; Pimbert, M.; Vanloqueren, G. Agroecological Research: Conforming—or Transforming the Dominant Agro-Food Regime? Agroecol. Sustain. Food Syst. 2014, 38, 1127-1155. [CrossRef]

30. Pimbert, M. Agroecology as an Alternative Vision to Conventional Development and Climate-smart Agriculture. Development 2015, 58, 286-298. [CrossRef]

31. Mockshell, J.; Villarino, E.J. Agroecological Intensification: Potential and Limitations to Achieving Food Security and Sustainability. In Encyclopedia of Food Security and Sustainability; Ferranti, P., Berry, E., Jock, A., Eds.; Elsevier: Amsterdam, The Netherlands, 2018; pp. 1-7. [CrossRef]

32. van der Ploeg, J.D.; Barjolle, D.; Bruil, J.; Brunori, G.; Costa Madureira, L.M.; Dessein, J.; Drag, Z.; Fink-Kessler, A.; Gasselin, P.; Gonzalez de Molina, M.; et al. The economic potential of agroecology: Empirical evidence from Europe. J. Rural. Stud. 2019, 71, 46-61. [CrossRef]

33. Wezel, A.; Goette, J.; Lagneaux, E.; Passuello, G.; Reisman, E.; Rodier, C.; Turpin, G. Agroecology in Europe: Research, Education, Collective Action Networks, and Alternative Food Systems. Sustainability 2018, 10, 1214. [CrossRef]

34. Ernesto Méndez, V.; Bacon, C.; Cohen, R. Introduction: Agroecology as a Transdisciplinary, Participatory, and Action-oriented Approach. Microb. Ecol. Sustain. Agroecosyst. 2015, 37, 1-22. [CrossRef]

35. Ferguson, R.S.; Lovell, S.T. Permaculture for agroecology: Design, movement, practice, and worldview. A review. Agron. Sustain. Dev. 2014, 34, 251-274. [CrossRef]

36. Mollison, B.; Holmgren, D. Permaculture 1: A Perennial Agriculture for Human Settlements; Tagari Publications: Tyalgum, Australia, 1978.

37. Henfrey, T.W. Designing for resilience: Permaculture as a transdisciplinary methodology in applied resilience research. Ecol. Soc. 2018, 23. [CrossRef]

38. Holmgren, D. Permaculture: Principles and Pathways Beyond Sustainability; Permanent Publications: East Meon, UK, 2011. 
39. Beckford, C.; Barker, D. The role and value of local knowledge in Jamaican agriculture: Adaptation and change in small-scale farming. Geogr. J. 2007, 173, 118-128. [CrossRef]

40. Smith, O.M.; Cohen, A.L.; Rieser, C.J.; Davis, A.G.; Taylor, J.M.; Adesanya, A.W.; Jones, M.S.; Meier, A.R.; Reganold, J.P.; Orpet, R.J.; et al. Organic Farming Provides Reliable Environmental Benefits but Increases Variability in Crop Yields: A Global Meta-Analysis. Front. Sustain. Food Syst. 2019, 3, 1-10. [CrossRef]

41. Crowder, D.W.; Reganold, J.P. Financial competitiveness of organic agriculture on a global scale. Proc. Natl. Acad. Sci. USA 2015, 112, 7611-7616. [CrossRef] [PubMed]

42. Gomiero, T.; Pimentel, D.; Paoletti, M.G. Environmental Impact of Different Agricultural Management Practices: Conventional vs. Organic Agriculture. Crit. Rev. Plant Sci. 2011, 30, 95-124. [CrossRef]

43. Seufert, V.; Ramankutty, N.; Mayerhofer, T. What is this thing called organic?-How organic farming is codified in regulations. Food Policy 2017, 68, 10-20. [CrossRef]

44. Conford, P. The Origins of the Organic Movement; Floris Books: Glasgow, UK, 2001.

45. Dudek, M.; Wrzaszcz, W. On the Way to Eco-Innovations in Agriculture: Concepts, Implementation and Effects at National and Local Level. The Case of Poland. Sustainability 2020, 12, 4839. [CrossRef]

46. Martínez-Torres, M.E.; Rosset, P.M. Diálogo de saberesin La Vía Campesina: Food sovereignty and agroecology. J. Peasant. Stud. 2014, 41, 979-997. [CrossRef]

47. Łukowska, M. Agro-Perma-Lab: Synergie Agroekologii i Permakultury. 2020. Available online: http://agropermalab.org/blog/ 2020/12/24/aplab-synergie-pdf/ (accessed on 10 December 2020).

48. Boyer, R.H.W. Grassroots Innovation for Urban Sustainability: Comparing the Diffusion Pathways of Three Ecovillage Projects. Environ. Plan. A Econ. Space 2015, 47,320-337. [CrossRef]

49. Šūmane, S.; Kunda, I.; Knickel, K.; Strauss, A.; Tisenkopfs, T.; Rios, I.D.I.; Rivera, M.; Chebach, T.; Ashkenazy, A. Local and farmers' knowledge matters! How integrating informal and formal knowledge enhances sustainable and resilient agriculture. J. Rural. Stud. 2018, 59, 232-241. [CrossRef]

50. Hermans, F.; Van Apeldoorn, D.; Stuiver, M.; Kok, K. Niches and networks: Explaining network evolution through niche formation processes. Res. Policy 2013, 42, 613-623. [CrossRef]

51. Janc, K.; Czapiewski, K.; Wójcik, M. In the starting blocks for smart agriculture: The internet as a source of knowledge in transitional agriculture. NJAS Wagening. J. Life Sci. 2019, 90, 100309. [CrossRef]

52. Wójcik, M.; Jeziorska-Biel, P.; Czapiewski, K. Between words: A generational discussion about farming knowledge sources. J. Rural. Stud. 2019, 67, 130-141. [CrossRef]

53. Conley, T.; Udry, C. Social learning through networks: The adoption of new agricultural technologies in Ghana. Am. J. Agric. Econ. 2001, 83, 668-673. Available online: https://www.jstor.org/stable/1245097 (accessed on 10 December 2020). [CrossRef]

54. Saint Ville, A.S.; Hickey, G.M.; Locher, U.; Phillip, L.E. Exploring the role of social capital in influencing knowledge flows and innovation in smallholder farming communities in the Caribbean. Food Secur. 2016, 8, 535-549. [CrossRef]

55. Kivimaa, P.; Hyysalo, S.; Boon, W.; Klerkx, L.; Martiskainen, M.; Schot, J. Passing the baton: How intermediaries advance sustainability transitions in different phases. Environ. Innov. Soc. Transit. 2019, 31, 110-125. [CrossRef] 